\title{
PENGARUH UKURAN PERUSAHAAN, NET PROFIT MARGIN, DEBT TO EQUITY RATIO, KEPEMILIKAN MANAJERIAL DAN REPUTASI AUDITOR TERHADAP PRAKTIK PERATAAN LABA (INCOME SMOOTHING) (Studi Kasus Pada Perusahaan Manufaktur Yang Terdaftar Di Bursa Efek Indonesia Tahun 2011 - 2014)
}

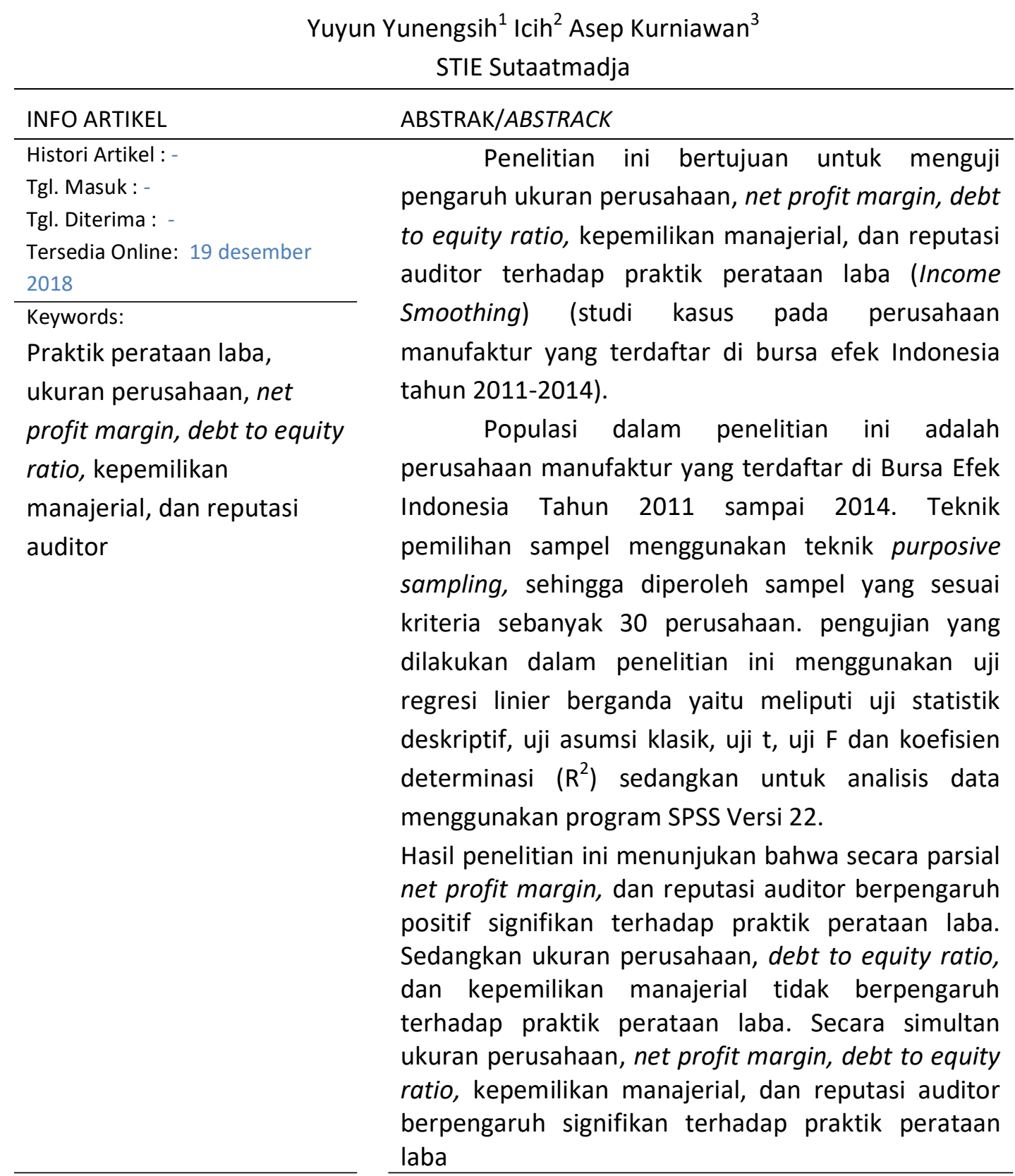

PENDAHULUAN

Perusahaan merupakan organisasi yang bertujuan untuk memperoleh laba. Laba merupakan hal yang sangat penting bagi kelangsungan hidup suatu perusahaan. Kelangsungan hidup perusahaan harus dapat dipertahankan dengan memperoleh keuntungan dan 
meningkatkan kesejahteraan perusahaan tersebut. Untuk itu perusahaan harus menunjukkan kinerja yang baik agar mampu menarik minat investor untuk melakukan investasi pada perusahaan (Primatama, willy 2015). Laporan keuangan merupakan salah satu alat untuk menilai kinerja perusahaan. Menurut Irham Fahmi (2014), mendefinisikan laporan keuangan merupakan suatu informasi yang menggambarkan kondisi keuangan suatu perusahaan, dan lebih jauh informasi tersebut dapat dijadikan sebagai gambaran kinerja keuangan perusahaan.

Semua laporan tersebut

bermanfaat dan penting dalam pengambilan keputusan. Namun, perhatian para pemakai laporan keuangan lebih terpusat pada informasi laba yang terdapat dalam laporan laba rugi. Sebagaimana disebutkan dalam Statement of Financial Accounting Concept (SFAC) No 1 dalam Yuyetta dan Noviana (2011), menyatakan bahwa: "informasi laba merupakan perhatian utama untuk menaksir kinerja atau pertanggungjawaban manajemen dan informasi laba membantu pemilik atau pihak lain melakukan penaksiran atas earning power perusahaan dimasa yang akan datang".

Dengan adanya pernyataan tersebut, dalam hal ini manajemen selaku pihak yang telah diberi wewenang dan kepercayaan penuh oleh principal untuk mengelola bisnis perusahaan sering kali merasa terbebani dalam menghadapi tekanan-tekanan untuk memenuhi target kerja jangka pendek. Karena tekanantekanan inilah yang pada akhirnya akan memaksa manajemen untuk selalu melakukan perubahan-perubahan strategi bisnis maupun melakukan earning management dalam proses pelaporan keuangannya. Pentingnya informasi laba disadari oleh manajemen, sehingga manajemen cenderung melakukan disfunctional behaviour (perilaku tidak semestinya) yang dipengaruhi oleh adanya asimetri informasi dalam konsep teori keagenan. Dimana tiap-tiap pihak, baik principal maupun agent mempunyai perbedaan kepentingan dan ingin memperjuangkan kepentingannya masing-masing, selain itu agent memiliki informasi lebih banyak mengenai perusahaan di bandingkan principal. Sehingga mendorong manajer untuk melakukan manajemen laba atau manipulasi atas laba dalam bentuk perataan laba (Assih dan Gudono, 2000 dalam Rahmawati dan Muid, 2012).

Manajemen laba merupakan setiap tindakan manajemen yang dapat mempengaruhi angka laba yang dilaporkan. Setiawati (2002) dalam Herawati (2010) menyatakan manajemen laba sebagai campur tangan manajemen dalam proses pelaporan eksternal dengan tujuan menguntungkan dirinya sendiri (manajer). Dari beberapa pola manajemen laba, menurut Dewi (2011) pola yang sering digunakan oleh manajemen untuk memaksimalkan kepentingannya sendiri ataupun kepentingan perusahaan yaitu teknik perataan laba (income smoothing). Perataan laba didefinisikan sebagai pengurangan fluktuasi laba yang saat ini dianggap normal oleh perusahaan. Dengan kata lain, perataan laba mencerminkan suatu usaha manajemen 
perusahaan untuk menurunkan variasi yang abnormal dalam laba sejauh yang di izikan oleh prinsip-prinsip akuntansi dan manajemen yang baik (Bidleman,1973 dalam Belkaoui riahi, 2007).

Tindakan perataan laba ini bukan usaha untuk membuat laba suatu periode sama dengan jumlah laba pada periode sebelumnya, karena dalam mengurangi fluktuasi laba juga mempertimbangkan tingkat pertumbuhan normal yang di harapkan pada periode tersebut. Praktik perataan laba dianggap sebagai tindakan rasional yang dilakukan oleh pihak manajemen, karena tidak keluar dari prinsip-prinsip akuntansi yang diizinkan dan masih dalam batasan standar akuntansi keuangan yang berlaku, namun dalam hal ini manajemen perusahaan mencari celah bagaimana ia melakukan hal tersebut tanpa melanggar aturan akuntansi dan memanfaatkan kebijakannya dalam pemilihan metode akuntansi yang akan digunakan. Sehingga, dapat dikatakan praktik perataan laba merupakan suatu seni mengatur laba dalam laporan keuangan, agar laba dalam laporan keuangan yang disajikan menjadi sesuai dengan tingkat normal laba yang diinginkan manajemen tersebut (Yasa dan Manuari, 2014).

Mengacu pada uraian di atas, terdapat fenomena mengenai praktik perataan laba yang dilakukan oleh salah satu perusahaan manufaktur yaitu PT Indofarma Tbk, melakukan kesalahan pencatatan dalam laporan keuangan, yang mana berdasarkan hasil pemeriksaan Bapepam (Badan Pengawas Pasar Modal, 2004) terhadap PT Indofarma Tbk, ditemukan bukti bahwa nilai barang dalam proses dinilai lebih tinggi dari nilai yang seharusnya dalam penyajian nilai persediaan dalam proses pada tahun buku 2001 yaitu sebesar Rp 28,87 miliar. Akibatnya penyajian akun persediaan terlalu tinggi (overstated) sebesar $\mathrm{Rp}$ 28,87 miliar, dan harga pokok penjualan juga disajikan terlalu rendah (understated) sebesar Rp 28,87 miliar, sehingga laba bersih pun disajikan terlalu tinggi dengan nilai yang sama. Salah satu penyebab disajikannya laba bersih yang terlalu tinggi itu adalah untuk mengurangi fluktuasi laba yang signifikan dari periode sebelumnya.

Tindakan tersebut akan membuat angka laba perusahaan menjadi berubah dan tanpa disadari akan membuat distorsi dalam pengambilan keputusan oleh pihak investor yang akan menanamkan dananya di perusahaan, karena perhatian investor hanya melihat tingkatan laba tanpa mengetahui prosedur yang digunakan dalam memperoleh laba tersebut. Dengan adanya fenomena dan pernyataan di atas, maka perlu dikaji untuk mengetahui faktor-faktor apa saja yang mempengaruhi manajemen melakukan praktik perataaan laba.

Sehingga, tujuan penelitian ini untuk mengetahui seberapa besar pengaruh ukuran perusahaan, net profit margin, debt to equity ratio, kepemilikan manajerial, dan reputasi auditor terhadap praktik perataan laba. Objek penelitian yang digunakan yaitu perusahaan manufaktur yang terdaftar di Bursa efek Indonesia. Alasan menggunakan perusahaan manufaktur yaitu perusahaan manufaktur terdiri dari bebagai sub sektor industri yang dapat mencerminkan reaksi investor terhadap angka laba yang dilaporkan pihak perusahaan secara 
keseluruhan. Tahun yang digunakan dalam penelitian ini mulai dari tahun 2011 hingga 2014. Karena, pada tahun tahun 2011-2014 industri manufaktur memberikan kontribusi yang sangat besar terhadap perekonomian Indonesia. sehingga dapat mendorong minat investor untuk berivestasi.

\section{LITERATUR REVIEW DAN HIPOTESIS}

Jensen dan Meckling (1976) dalam

Watts dan Zimmerman (1986):

"menyatakan bahwa teori keagenan

disebut juga sebagai teori kontraktual yang memandang suatu perusahaan sebagai suatu perikatan kontrak antara anggota-anggota perusahaan". Lebih lanjut, mereka menyatakan hubungan keagenan sebagai suatu kontrak jasa antara satu atau lebih pihak (prinsipal) yang memperkerjakan pihak lain (agen) untuk melakukan suatu jasa untuk kepentingan mereka yang meliputi pendelegasian beberapa kekuasaan pengambilan keputusan kepada agen tersebut.

Dalam hubungan keagenan, manajer selaku agent memiliki infomasi yang asimetri kepada pihak-pihak eksternal perusahaan, seperti kreditor dan investor. Informasi yang asimetri ini terjadi ketika manajer memiliki informasi internal (tentang prospek, resiko dan nilai perusahaan) yang lebih cepat, banyak serta akurat, hal ini disebabkan manajemen mempunyai kemampuan untuk mengakses informasi internal perusahaan secara lebih leluasa dibandingkan dengan pihak pemegang saham (principal) serta pihak eksternal lainnya. Teori agensi mengasumsikan bahwa semua individu bertindak untuk kepentingan mereka sendiri. Dari uraian diatas, maka dapat disimpulkan bahwa dengan adanya perbedaan kepentingan antara principal dan agent dapat menimbulkan pertentangan, hal tersebut berpotensi menimbulkan terjadinya asimetri informasi. Dengan adanya asimetri informasi antara pemilik dengan manajemen akan memberi kesempatan kepada manajer untuk melakukan praktik perataan laba.

Teori Akuntansi Positif (Positive Accounting Theory)

Rahmawati dan Muid (2012): "menyatakan bahwa praktik perataan laba terkait dengan teori akuntansi positif. Scott (2006) dalam Noviana (2012) mendefinisikan Teori Akuntansi Positif (contracting theory) adalah teori yang memprediksi tindakan pemilihan kebijakan akuntansi oleh manajer dan bagaimana manajer akan merespon kebijakan akuntansi baru yang diusulkan". Tujuan teori akuntansi adalah untuk menjelaskan dan memprediksi praktek akuntansi (Menurut Watt \& Zimmerman, 1986 dalam Noviana, 2012).

\section{Laporan Keuangan}

Menurut (Baridwan 1997:17): "Laporan keuangan merupakan ringkasan dari suatu proses pencatatan transaksitransaksi keuangan yang terjadi selama tahun buku yang bersangkutan". Seiring dengan hal tersebut Standard Financial $\begin{array}{llll}\text { Accounting Concep } & \text { (SFAC) No.1 }\end{array}$ menyatakan bahwa tujuan dari pelaporan keuangan perusahaan yaitu menyediakan informasi yang bermanfaat bagi pembuatan keputusan bisnis dan ekonomis oleh investor yang ada dan yang potensial, kreditor, manajemen, 
pemerintah dan pengguna lainnya (FASB, 1978 dalam Irham Fahmi, 2014:24).

\section{Laba}

Laba merupakan salah satu elemen yang potensial yang terdapat dalam laporan keuangan. Menurut Committee on Therminology dalam Sofyan Syafri $\mathrm{H}$ (2011:245) mendefinisikan: "laba sebagai jumlah yang berasal dari pengurangan harga pokok produksi, biaya lain, dan kerugian dari penghasilan atau penghasilan operasi". Kemudian menurut APB Statement mengartikan: "laba (rugi) sebagai kelebihan (defisit) penghasilan diatas biaya selama satu tahun periode akuntansi".

\section{Manajemen Laba}

Manajemen laba dapat didefinisikan dalam

membagi definisi manajemen laba menjadi dua, yaitu :

2. Definisi Sempit

Earning management dalam hal ini hanya berkaitan dengan pemilihan metode akuntansi. Earning management dalam artian sempit didefinisikan sebagai perilaku manager untuk "bermain" dengan komponen discretionary accrual dalam penentuan besarnya laba.

3. Definisi Luas

Earning management merupakan tindakan manajer untuk meningkatkan (mengurangi) laba yang dilaporkan saat ini atas unit dimana manajer bertanggungjawab, tanpa mengakibatkan peningkatan (penurunan) profitabilitas ekonomi jangka panjang unit tersebut.

Pola Manajemen Laba
Scott (2000) mengidentifikasikan manajemen laba ke dalam beberapa pola yaitu sebagai berikut :

2. Smoothing. Pola manajemen laba tersebut dapat dijelaskan sebagai berikut : Taking a bath

3. Income Minimization

4. Income Maximization

5. Income Smoothing

\section{Perataan Laba}

Menurut Belkoui menyatakan: "Definisi awal mengenai perataan laba adalah pengurangan fluktuasi laba dari tahun ketahun dengan memindahkan pendapatan dari tahun yang tinggi pendapatannya ke periodeperiode yang kurang menguntungkan". Sedangkan definisi lebih modern

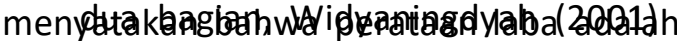
fenomena proses manipulasi profil waktu dari pendapatan atau laporan pendapatan untuk membuat laporan laba menjadi kurang bervariasi, sambil sekaligus tidak meningkatkan pendapatan yang dilaporkan selama periode tersebut.

Income smoothing dapat bersifat positif atau negatif, namun kecenderungan saat ini banyak pihak yang menganggap income smoothing sebagai tindakan memanipulasi atau tidak sesuai dengan kondisi yang sebenarnya namun diperbolehkan dengan prinsip standar akuntansi yang berlaku. Akuntansi dengan standar yang berlaku, merupakan sebuah alat yang digunakan manajemen (dengan bantuan akuntan) untuk menyajikan laporan keuangan. Pada umumnya praktik akuntansi tidak lepas dari kebijakan manajemen dalam memilih metode akuntansi yang sesuai dan diperbolehkan (Simbolon, 2010 dalam Septia sari, 2014). 


\section{Dimensi Perataan Laba}

Dimensi perataan pada dasarnya adalah alat yang digunakan untuk menyelesaikan perataan angka pendapatan (Belkoui Riahi, 2007:195). Terdapat berbagai media atau dimensi yang digunakan untuk meratakan laba. Dascher dan Malcom dalam Belkoui Riahi, (2007:195) membedakan antara perataan riil dan perataan artifisial sebagai berikut:

4. Riil Smoothing, berkaitan dengan transaksi aktual yang dilakukan atau tidak dilakukan berdasarkan pada pengaruh perataan laba.

5. Artificial Smoothing, berkaitan dengan prosedur akuntansi yang diimplementasikan untuk mengubah biaya dan/atau pendapatan dari satu periode ke periode yang lain.

6.

Disamping perataan riil dan artifisial, terdapat dimensi perataan lain yang disebutkan dalam literature. Suatu klasifikasi yang popular menambahkan dimensi ketiga, yang dinamakan perataan klasifikasi. Barnea et al dalam Belkoui Riahi (2007:196) membedakan antara ketiga perataan tersebut sebagai berikut :

a. Perataan melalui adanya kejadian dan/atau pengakuan

b. Perataan melalui alokasi terhadap waktu

c. Perataan melalui kalsifikasi (perataan laba melalui pengklasifikasian)

\section{Pengaruh Ukuran Perusahaan Terhadap Praktik Perataan Laba}

Ukuran perusahaan merupakan suatu skala yang mengklasifikasikan besar kecilnya suatu perusahaan dengan berbagai cara, antara lain: total aktiva, log size, nilai pasar saham dan lain-lain (machfoed 1994 dalam octaviani, 2014).
Biasanya ukuran perusahaan di ukur dengan menggunakan total asset perusahaan. Nasser dan Herlina (2003) dalam Rahmawati dan Muid (2012) beranggapan perusahaan yang memiliki total aset yang besar dapat disebut sebagai perusahaan besar dan akan mendapat lebih banyak perhatian dari berbagai pihak seperti para analis, investor maupun pemerintah. Perusahaan besar lebih cenderung melakukan praktik perataan laba dibandingkan perusahaan kecil karena perusahaan besar dianggap memiliki prosfek lebih luas untuk pengembangan usahanya dengan memiliki total asset yang besar dan lebih mudah dalam mendapat pendanaan dari pihak kreditur untuk menambah modal perusahaan.

Rahmawati dan Muid (2012) dalam penelitiannya menyatakan hasil bahwa ukuran perusahaan berpengaruh posiitif terhadap praktik perataan laba. Sedangkan penelitian Kusnadi (2015) menunjukan hasil bahwa ukuran perusahaan tidak berpengaruh signifikan terhadap parktik perataan laba. hal ini terjadi kemungkinan karena perusahaan yang semakin besar akan menjadi sorotan publik sehingga mereka cenderung untuk tidak melakukan perataan laba, selain itu transaksi pada perusahaan besar juga semakin kompleks sehingga praktek perataan laba semakin sulit untuk dilakukan. Dari penjelasan maka dapat di peroleh hipotesis sebagai berikut :

$\mathrm{H}_{1}$ : Ukuran Perusahaan berpengaruh positif terhadap praktik perataan laba

Pengaruh Net Profit Margin Terhadap Praktik Perataan Laba 
Net profit margin merupakan bagian dari profitabilitas perusahaan melalui pengukuran antara laba bersih setelah pajak dengan total penjualan, dimana laba bersih setelah pajak sering digunakan oleh investor sebagai dasar pengambilan keputusan ekonomi yang berhubungan dengan perusahaan (Azhari, 2010 dalam Rahmawati dan Muid, 2012).

Margin penghasilan bersih ini sering dijadikan tujuan perataan laba oleh manajemen untuk mengurangi fluktuasi laba dan menunjukkan kepada pihak luar bahwa kinerja manajemen perusahaan telah efektif (Rahmawati dan Muid, 2012). Karena, menurut Dewi (2012) menyatakan bahwa jika ada variabilitas laba yang besar manajer akan cenderung melakukan perataan dengan harapan bahwa profitabilitas yang tinggi akan menaikkan standar bonus/laba di masa yang akan datang dan mengurangi kekhawatiran manajer dalam pencapaian target laba yang stabil di masa yang akan datang.

Dalam hal ini, perusahaan dengan tingkat net profit margin yang rendah pada tahun sebelumnya, maka kecenderungan manajer untuk melakukan perataan laba semakin besar dengan tujuan untuk meningkatkan kembali nilai profitabilitas perusahaan, karena dengan tingkat profitabilitas yang tinggi akan dapat menaikkan standar bonus atau laba dimasa yang akan datang. Berdasarkan uraian tersebut, maka dirumuskan hipotesis sebagai berikut:

$\mathrm{H}_{2}$ : Net Profit Margin berpengaruh positif terhadap praktik perataan laba

Pengaruh Debt to Equity Ratio Terhadap Praktik Perataan Laba
Debt to Equity ratio merupakan: "bagian dari rasio leverage perusahaan. Rasio ini menunjukan kemampuan modal perusahaan untuk memenuhi seluruh kewajibannya (bagian dari setiap rupiah modal sendiri yang dijadikan jaminan untuk keseluruhan utang)". Dengan itu dapat dikatakan bahwa semakin tinggi Debt to equity ratio menunjukan komposisi total hutang semakin besar dibanding dengan total modal sendiri, sehingga berdampak semakin besar beban perusahaan terhadap pihak luar (kreditur) atau dengan kata lain semakin rendah tingkat pendanaan dari kreditur untuk mendukung kegiatan operasional perusahaan yang dapat berdampak pada penurunan laba perusahaan. $\mathrm{Hal}$ ini karena biasanya kreditur akan memberikan kredit pada perusahaan yang mempunyai laba yang tinggi atau stabil, karena laba yang stabil memberikan keyakinan pada kreditur bahwa perusahaan akan mampu membayar hutangnya dengan lancar (Rahmawati dan Muid, 2012). Sehingga dengan nilai debt to equity ratio yang tinggi akan mengindikasikan manajer untuk melakukan praktik perataan laba karena untuk menghindari perjanjian persyaratan utang dengan pihak kreditur.

$$
\text { Penelitian Kusnadi }
$$

membuktikan hasil bahwa debt to equity ratio berpengaruh positif terhadap praktik perataan laba. Sedangkan penelitian Rahmawati dan Muid (2012) menyatakan bahwa: "debt to equity ratio tidak berpengaruh signifikan terhadap praktik perataan laba karena sampel pada perusahaan yang diteliti memiliki tingkat utang yang rendah atau dengan kata lain 
perusahaan tidak bergantung pada utang dalam membiayai modal perusahaan dan penggunaan DER. Berdasarkan uraian tersebut, maka dapat dirumuskan hipotesis sebagai berikut :

$\mathrm{H}_{3}$ : Debt to Equity Ratio berpengaruh positif terhadap praktik perataan laba

\section{Pengaruh Kepemilikan Manajerial Terhadap Praktik Perataan Laba}

Kepemilikan manajerial merupakan jumlah saham yang dimiliki pihak manajemen seperti manajer, dewan komisaris dan dewan direksi dalam perusahaan. Keberadaan kepemilikan saham manajerial dalam perusahaan akan dapat mensejajarkan kepentingan antara pemegang saham dengan manajer perusahaan dan dianggap sebagai kegiatan monitoring dalam perusahaan karena manajer tersebut berperan sebagai pemegang saham juga sebagai pengawas perusahaan yang menginginkan laporan keuangan yang dibuat oleh pihak manajer memberikan informasi yang bersifat relevan dan dapat dipertanggungjawabkan kebenaran informasinya. Dengan demikian informasi yang diberikan oleh manajer kepada pemegang saham akan lebih objektif dan tidak memiliki perbedaan informasi.

Sehingga dengan proporsi kepemilikan manajerial yang tinggi dalam perusahaan akan mempersempit peluang manajer untuk melakukan manipulasi laba dalam bentuk praktik perataan laba. Penelitian Kusnadi (2015) menunjukan hasil bahwa kepemilikan manajerial berpengaruh negatif terhadap praktik perataan laba. Sedangkan penelitian Octaviani dan Asyik (2014) menyatakan kepemilikan manajerial tidak berpengaruh signifikan terhadap praktik perataan laba. karena kepemilikan saham manajerial yang rendah atau minoritas. Berdasarkan uraian tersebut, maka dapat dirumuskan hipotesis sebagai berikut:

$\mathrm{H}_{4}$ : Kepemilikan manajerial berpengaruh negatif terhadap praktik perataan laba

Pengaruh Reputasi Auditor Terhadap Praktik Perataan Laba

Keberadaan auditor dalam perusahaan yaitu berperan sebagai pihak independen antara principal dengan agent dalam konflik keagenan yang dihadapi dalam perusahaan. Dalam hal ini principal selaku pemegang saham akan menggunkan laporan keuangan yang di buat oleh manajemen perusahaan yang sudah diaudit oleh seorang auditor sebagai pengambilan keputusan karena dapat menggambarkan kebenaran dalam pelaporan keuangan. Kualitas auditor dapat diukur dengan menggunakan reputasi auditor dari KAP yang bergabung dengan auditor tersebut. Sulistyawati (2013) menyatakan auditor eksternal yang dianggap berkualitas adalah auditor yang tergabung dalam KAP the big four. Auditor dari KAP the big four dianggap sebagai auditor yang memiliki keahlian dan bereputasi lebih tinggi dibandingkan dengan auditor dari KAP non big four.

Sehingga kualitas audit dari KAP yang besar menjadi salah satu pertimbangan manajemen untuk melakukan menipulasi laba perusahaan. penggunaan jasa auditor yang memiliki reputasi yang tinggi pada perusahaan akan cenderung manajemen untuk tidak melakukan praktik perataan laba. karena auditor dari KAP the big four merupakan 
auditor yang berkualitas dan lebih teliti dan cermat dalam memeriksa laporan keuangan perusahaan. sehingga auditor dari KAP the big four mampu mendeteksi kecurangan yang di lakukan manajemen perusahaan dalam penyusunan laporan keuangan. Sesuai dengan hasil penelitian firdaus (2015) yang menunjukan hasil reputasi auditor berpengaruh signifikan terhadap perilaku perataan laba serta penelitian Herni dan Susanto (2008) dalam Sulistiyawati (2013) menyatakan hasil reputasi auditor memiliki pengaruh negatif terhadap praktik perataan laba. Demikian berdasarkan uraian tersebut dapat dirumuskan hipotesis sebagai berikut:

$\mathrm{H}_{5}$ : Reputasi auditor bepengaruh negatif terhadap praktik perataan laba

Pengaruh Ukuran Perusahaan, Net Profit Margin, Debt to Equity Ratio, Kepemilikan Manajerial, dan Reputasi Auditor Terhadap Praktik Perataan Laba

Perataan laba (Income smoothing) mencerminkan suatu usaha manajemen perusahaan untuk menurunkan variasi yang abnormal dalam laba sejauh yang diizinkan oleh prinsip-prinsip akuntansi dan manajemen yang baik (Bidleman dalam Belkaoui riahi, 2007). Adanya praktik perataan laba dapat dikatakan sebagai usaha untuk memperkecil laba yang dilaporkan jika laba aktual lebih besar dari laba normal dan usaha untuk memperbesar laba yang dilaporkan jika laba aktual lebih kecil dari laba normal, karena salah satu tujuan dilakukannya perataan laba adalah untuk memberika rasa aman kepada investor karena kemungkinan fluktuasi laba yang kecil akan meningkatkan dan memberikan kemampuan investor untuk meramalkan laba perusahaan pada periode mendatang (Abiprayu dan Irene, 2011 dalam Handayani dan pratiwi, 2014).

Tindakan perataan laba ini yang dilakukan oleh pihak manajemen perusahaan dipengaruhi oleh beberapa faktor diantaranya ukuran perusahaan, debt to equity ratio, net profit margin, kepemilikan manajerial dan reputasi auditor. Hipotesis dalam penelitian ini tidak hanya di lakukan secara parsial untuk mengetahui pengaruh variabel independen terhadap variabel dependen, maka diperlukan juga pengujian secara simultan pengaruh dari ukuran perusahaan, debt to equity ratio, net profit margin, kepemilikan manajerial dan reputasi auditor terhadap praktik perataan laba. Berdasarkan uraian diatas dirumuskan hipotesis sebagai berikut:

$\mathrm{H}_{6}$ : Ukuran perusahaan debt to equity ratio, net profit margin, kepemilikan manajerial dan reputasi auditor berpengaruh secara simultan terhadap praktik perataan laba.

\section{METODELOGI PENELITIAN}

Jenis, Sumber, dan Teknik Pengumpulan Data

Data yang digunakan dalam penelitian ini adalah data sekunder. Sumber data yang digunakan dalam penelitian ini adalah berupa laporan keuangan tahunan perusahaan manufaktur yang terdaftar di Bursa Efek Indonesia tahun 2011-2014. Untuk memperoleh data penelitian, teknik pengumpulan data yang digunakan dalam penelitian ini adalah studi dokumentasi, dan studi kepustakaan.

Populasi dan Sampel 
Populasi yang diambil dalam penelitian ini yaitu seluruh perusahaan manufaktur yang terdaftar di Bura Efek Indonesia (BEI). Teknik pengumpulan sampel yang digunakan adalah teknik purposive sampling.

Adapun kriteria yang digunakan dalam penentuan sampel pada penelitian ini adalah sebagai berikut:

b. Perusahaan manufaktur yang terdaftar di Bursa Efek Indonesia yang mempublikasikan Annual Report dan Laporan Keuangan yang berakhir 31 Desember dan telah diaudit pada tahun 2011-2014

c. Perusahaan manufaktur yang laporan keuangannya dari tahun 2011-2014 tidak mengalami kerugian secara berturut-turut

d. Perusahaan manufaktur yang mencantumkan data kepemilikan saham manajerial untuk proksi dari kepemilikan manjerial

e. Perusahaan manufaktur yang memiliki kelengkapan data dalam laporan keuangan yang dibutuhkan untuk proses penelitian

Dari 142 perusahaan manufaktur yang terdaftar di Bursa Efek Indonesia, sampel yang diperoleh sebanyak 30 perusahaan. Sehingga jumlah data observasi yang digunakan secara keseluruhan dari tahun 2011-2014 diperoleh sebanyak 120 data. Berdasarkan kriteria yang telah di tetapkan, berikut adalah tabel pemilihan kriteria sampel yang ditetapkan:

Tabel 1

Kriteria Sampel Berdasarkan Penelitian

\begin{tabular}{|c|l|c|}
\hline No & \multicolumn{1}{|c|}{ Kriteria } & Jumlah \\
\hline \multirow{3}{*}{1} & $\begin{array}{l}\text { Perusahaan Manufaktur yang } \\
\text { terdaftar di Bursa Efek } \\
\text { Indonesia (BEI) Tahun 2011- } \\
2014\end{array}$ & 142 \\
\hline
\end{tabular}

\begin{tabular}{|c|c|c|}
\hline 2 & $\begin{array}{l}\text { Perusahaan yang baru listing } \\
\text { di Bursa Efek Indonesia (BEI) } \\
\text { tahun 2011-2014 }\end{array}$ & (19) \\
\hline 3 & $\begin{array}{l}\text { Perusahaan manufaktur yang } \\
\text { mengalami kerugian secara } \\
\text { berturut-turut tahun 2011- } \\
2014\end{array}$ & (8) \\
\hline 4 & $\begin{array}{lr}\text { Perusahaan yang } & \text { tidak } \\
\text { menampilkan } & \text { data } \\
\text { kepemilikan } & \text { saham } \\
\text { manajerial tahun } & \text { 2011-2014 }\end{array}$ & (59) \\
\hline \multirow[t]{4}{*}{5} & $\begin{array}{l}\text { Perusahaan yang tidak } \\
\text { memiliki kelengkapan data } \\
\text { selama periode pengamatan }\end{array}$ & $(26)$ \\
\hline & $\begin{array}{l}\text { Jumlah Perusahaan } \\
\text { Manufaktur yang dijadikan } \\
\text { sampel }\end{array}$ & 30 \\
\hline & $\begin{array}{lll}\text { Lamanya } & \text { Tahun } & \text { yang } \\
\text { digunakan } & & \end{array}$ & 4 tahun \\
\hline & Total sampel (30 X 4 Thn) & 120 \\
\hline
\end{tabular}

Sumber: data diolah (2016)

Variabel Penelitian

Dalam penelitian ini terdapat lima variabel independen yaitu ukuran perusahaan, net profit margin, debt to equity ratio, kepemilikan manajerial, dan reputasi auditor dan satu variabel dependen yaitu Perataan laba.

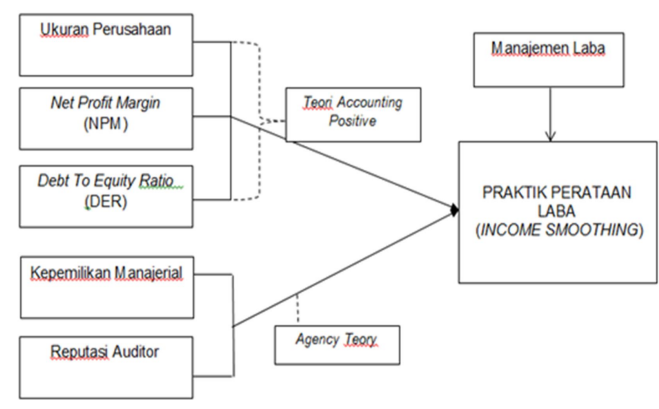

Gambar 1

Kerangka Penelitian

Sumber : Penulis (2016)

\section{Ukuran Perusahaan}

Ukuran perusahaan merupakan suatu skala yang dapat diklasifikasikan besar kecil suatu perusahaan menurut berbagai cara, antara lain dengan: total 
aktiva, log size, nilai pasar saham, dan lain-lain. Penentuan ukuran perusahaan didasarkan kepada total aktiva perusahaan (Machfoedz, 1994 dalam Octaviani dan Asyik, 2014). Adapun rumus yang digunakan dalam penelitian ini sebagai berikut:

Ukuran Perusahaan (UP) = Logaritma natural (Ln) Total Asset perusahaan

\section{Net Profit Margin (NPM)}

Net profit margin (NPM) diguanakan untuk menunjukan kemampuan perusahaan dalam mengahsilkan keuntungan bersih setelah dipotong pajak terhadap penjualan. Rasio ini menunjukan berapa besar persenatse laba bersih yang diperoleh dari setiap penjualan. Maka semakin besar rasio ini, maka semakin besar rasio ini, dianggap semakin baik kemampuan perusahaan untuk mendaptkan laba yang tinggi (Dewi dan Praseiono, 2012). Adapun rumus yang digunakan dalam penelitian ini yaitu:

Net Profit Margin (NPM) = $\frac{\text { Laba Bersih }}{\text { Total Penjualan }} \times 100 \%$

\section{Debt to Equity Ratio (DER)}

Debt to equity ratio (DER) yaitu menggambarkan komposisi atau struktur modal perusahaan yang diguknakan sebagai sumber pendanaan usaha. Semakin tinggi Debt to equity ratio, maka semakin tinggi komposisi utang perusahaan diabndingkan dengan modal sendiri. Sehingga berdampak besar paa beban perusahaan terhadap pihak luar (kreditor) (Dewi dan Prasetiono, 2012). Adapun rumus yang digunakan dalam penelitian ini yaitu:

\author{
Debt to Equity Ratio (DER) = \\ $\frac{\text { Total utang }}{\text { Total modal }} \times 100 \%$
}

Kepemilikan Manajerial

Octaviani dan Asyik (2014) mendefinisikan kepemilikan manajerial adalah: "kepemilikan saham perusahaan oleh pihak manajemen perusahaan. Kepemilikan manajerial menunjukan besarnya persentase dari jumlah saham yang dimiliki manajer, dewan komisaris dan dewan direksi". Dengan adanya kepemilikan manajerial dalam perusahaan dapat mengurangi konflik keagenan antara manajer dan pemegang saham. Adapun rumus yang digunakan yaitu: KM

Jumlah saham yang dimiliki dewan komisaris dan dewan direksi

Total saham yang beredar

\section{Reputasi Auditor}

Reputasi auditor merupakan penilaian terhadap kualitas auditor dalam melakukan audit (Prabayanti dan Yasa, 2011). Reputasi auditor merupakan variabel dummy yaitu diberikan nilai 1 , apabila perusahaan menggunakan KAP The BIG Four dan diberikan nilai 0, apabila perusahaan menggunakan KAP Non-Big Four

\section{Perataan Laba}

Perataan laba merupakan suatu usaha manajemen perusahaan untuk menurunkan variasi yang abnormal dalam laba yang diizinkan oleh prinsip akuntansi dan manajemen yang baik (Belkaoui, 2007). Praktik perataan laba diukur dengan menggunakan indeks eckel (1981) yang dirumuskan sebagai berikut: 
Keterangan:

$$
\text { Indek Perataan Laba }=\frac{\mathrm{CV} \Delta \mathrm{I}}{\mathrm{CV} \Delta \mathrm{S}}
$$

CV : Koefisien variasi yaitu standar deviasi dibagi dengan nilai yang diharapkan

$\Delta \mathrm{l}$ : Perubahan pendapatan satu periode

$\Delta S$ : Perubahan laba bersih dalam satu periode

Nilai CVAI dan CV $\Delta S$ dapat diperoleh sebagai berikut :

Nilai CV $\Delta \mathrm{I}$ dan $\mathrm{CV} \Delta \mathrm{S}=\sqrt{\sum \frac{(\Delta \mathrm{x}-\overline{\Delta \mathrm{x}})^{2}}{n-1}}: \overline{\Delta \mathrm{x}}$

Dimana:

$\Delta \mathrm{x}$ : Perubahan laba bersih (I) atau penjualan ( $\mathrm{S}$ ) antara tahun $\mathrm{n}$ dengan $\mathrm{n}-1$

$\overline{\Delta \mathrm{x}}$ : Rata-rata perubahan laba bersih atau penjualan

$\mathrm{n}$ : Banyaknya tahun yang diamati

Keterangan :

Apabila nilai indeks perataan laba $<1$ atau (CV $\Delta \mathrm{I}<\mathrm{CV} \Delta \mathrm{S}$ ) berarti perusahaan digolongkan melakukan perataan laba. sedangkan apabila nilai indek perataan laba $\geq 1$ atau $(\mathrm{CV} \Delta \mathrm{I}>\mathrm{CV} \Delta \mathrm{S})$ berarti perusahaan digolongkan tidak melakukan perataan laba. (Octaviani dan Asyik, 2014)

\section{Metode Analisis Data}

Penelitian ini menggunakan metode statistik deskriptif, uji normalitas data (uji Kolmogorov-Smirnov) dan uji data outlier, kemudian dilakukan uji asumsi klasik yang terdiri dari uji multikolinearitas, uji autokorelasi, uji heteroskedastisitas, uji normalitas dan uji linearitas dan selanjutnya dilakukan pengujian hipotesis dengan menggunakan analisis regresi linier berganda, perhitungan uji statistik secara parsial (Uji

\begin{tabular}{|l|l|c|c|c|c|}
\hline \multicolumn{2}{|c|}{} & \begin{tabular}{c} 
Fr \\
eq \\
\multicolumn{2}{|c|}{}
\end{tabular} & $\begin{array}{c}\text { Per } \\
\text { cen } \\
\text { t }\end{array}$ & $\begin{array}{c}\text { Valid } \\
\text { Percen } \\
\text { t }\end{array}$ & $\begin{array}{c}\text { Cum. } \\
\text { Percen } \\
\text { t }\end{array}$ \\
\hline $\begin{array}{l}\text { REPU } \\
\text { TASI }\end{array}$ & $\begin{array}{l}\text { KAP Non } \\
\text { AUD Four }\end{array}$ & 70 & 58. & 58.3 & 58.3 \\
\cline { 2 - 6 } TOR & KAP The & 50 & 41. & 41.7 & 41.7 \\
\cline { 2 - 6 } & Big Four & & 7 & & \\
\cline { 2 - 6 } & Total & $\begin{array}{c}12 \\
0\end{array}$ & 100 & 100 & \\
\hline
\end{tabular}

Signifikansi-t), perhitungan uji statistik secara simultan (Uji Signifikansi-F), dan uji koefisien determinasi $\left(R^{2}\right)$. Program computer (software) yang digunakan dalam penelitian ini adalah SPSS 22.0 version dan Microsoft Excel 2010.

\section{HASIL DAN PEMBAHASAN}

\section{Analisis Statistik Deskriptif}

Deskriptif data untuk setiap variabel yang digunakan dalam analisis adalah sebagaimana ditunjukkan pada tabel dibawah sebagai berikut:

Tabel 2

Statistik Deskriptif I

\begin{tabular}{|l|c|c|c|c|c|}
\hline & $\mathbf{N}$ & $\mathbf{n .}$ & $\cdot$ & Mean & $\begin{array}{c}\text { Std. } \\
\text { Deviatio } \\
\mathbf{n}\end{array}$ \\
\hline SIZE & $\begin{array}{c}12 \\
0\end{array}$ & 25.19 & $\begin{array}{c}32.0 \\
9\end{array}$ & $\begin{array}{c}28.206 \\
0\end{array}$ & 1.69119 \\
\hline NPM & $\begin{array}{c}12 \\
0\end{array}$ & -.34 & .52 & .0738 & .08950 \\
\hline DER & $\begin{array}{c}12 \\
0\end{array}$ & .08 & 4.01 & .8193 & .70523 \\
\hline KPMJ & $\begin{array}{c}12 \\
0\end{array}$ & .00 & .28 & .0489 & .08273 \\
\hline IS & $\begin{array}{c}12 \\
0\end{array}$ & -12.39 & 8.07 & .3287 & 1.82623 \\
\hline $\begin{array}{l}\text { Valid N } \\
\text { (listwis } \\
\text { e) }\end{array}$ & $\begin{array}{c}12 \\
0\end{array}$ & & & & \\
\hline
\end{tabular}

Sumber: Output SPSS Ver 22.0

Tabel 3 


\section{Statistik Deskriptif II}

Sumber: Output SPSS Ver 22.0

\section{Uji Normalitas Data (Uji Kolmogorov- Smirnov)}

Pengukuran normalitas data dalam penelitian ini adalah dengan melihat nilai signifikan pada setiap variabel penelitian. Berikut ini tabel hasil uji normalitas dalam penelitian ini:

Tabel 4

Uji Normalitas Kolmogorov-Smirnov

\begin{tabular}{|c|c|c|c|}
\hline \multirow{2}{*}{} & \multicolumn{3}{|c|}{ Kolmogorov-smirnov } \\
\cline { 2 - 4 } & Statistic & Df & Sig. \\
\hline SIZE & .074 & 120 & $.156^{\mathrm{C}}$ \\
NPM & .152 & 120 & $.000^{\mathrm{C}}$ \\
DER & .185 & 120 & $.000^{\mathrm{C}}$ \\
KPMJ & .334 & 120 & $.000^{\mathrm{C}}$ \\
RA & .383 & 120 & $.000^{\mathrm{C}}$ \\
IS & .227 & 120 & $.000^{\mathrm{C}}$ \\
\hline
\end{tabular}

Sumber: Output SPSS Ver 22.0

Dari tabel diatas terlihat bahwa variabel ukuran perusahaan yang disimbolkan dengan "SIZE" memiliki nilai signifikan 0,156 (>0,05) yang berarti variabel ukuran perusahaan berdistribusi normal. Sedangkan variabel net profit margin, debt to equity ratio, kepemilikan manajerial, dan reputasi auditor memiliki nilai signifikan $0,000(<0.05)$ yang berarti variabel ukuran perusahaan, net profit margin, debt to equity ratio, kepemilikan manajerial, dan reputasi auditor berdistribusi tidak normal.

\section{Uji Outlier Data}

Dari pengujian outlier didapatkan ukuran perusahaan memiliki 2 data/kasus outlier yaitu nomor 71 dan 72 . Net profit margin memiliki 2 data/kasus outlier yaitu no 24 dan 25. Dan memiliki 2 data/kasus ekstrimya yaitu no 19 dan 25. Debt to equity ratio memiliki 3 data/kasus ekstrim yaitu no 3, 4, dan 24. Dan memiliki 7 data/kasus outlier yaitu no $1,2,43,63$, 110, 111, dan 112. Kemudian kepemilikan manajerial memiiki 8 data/kasus ekstrim yaitu no $13,14,15,16,45,46,47$, dan 48 . Dan memiliki 8 data/kasus outlier yaitu no $25,60,82,83,97,98,99$, dan 100. Lalu variabel perataan laba memiliki 8 data/kasus ekstrim yaitu no $28,33,42,49$, 70, 73, 91, dan 98. Dan 5 data/kasus outlier yaitu no 37, 57, 71, 72, dan 81 . Dalam penelitian ini hanya mengeluakan data/kasus ekstrim, karena sudah dapat menggambarkan hasil yang lebih baik dibandingkan dengan mengeluarkan keduanya. Sehingga dari jumlah sampel penelitian sebanyak 120 berubah menjadi 99 data.

\section{Uji Asumsi Klasik}

Pada penelitian ini terdapat 5 asumsi klasik yang harus dilakukan yaitu Uji Multikolinearitas, Uji Autokorelasi, Uji Normalitas, Uji Heteroskedastisitas, dan Uji Linearitas. Pada Uji Multikolinearitas menunjukan bahwa kelima variabel independen memiliki tolerance value $>0,1$ dan $\mathrm{VIF}<10$, jadi tidak terdapat hubungan multikolineritas.

Berdasarkan hasil uji autokorelasi didapat angka sebesar 1,973 yang berada diantara 1,7799 - 2,2201 yang artinya tidak menolak Ho, dengan demikian penelitian ini terbebas dari masalah autokorelasi. Hasil uji heterokedastisitas menunjukkan bahwa model regresi tidak mengalami gangguan heterokedastisitas. Hal ini dapat terlihat titik-titik tersebar tanpa membentuk suatu pola tertentu dan tersebar baik dibawah atau diatas angka 0 pada sumbu $Y$. 
Selanjutnya pada uji normalitas grafik histogram menunjukkan pola berdistribusi normal yaitu grafik membentuk pola lonceng, begitu juga dengan grafik normal p-plot yang menunjukkan titik-titik menyebar disekitar garis diagonal, hal ini berarti data residual terdistribusi secara normal. Uji asumsi klasik terakhir adalah uji linearitas, hasilnya adalah hubungan seluruh variabel independen terhadap variabel dependen menunjukkan bahwa arah garis mengarah ke kanan atas, hal ini menunjukkan hubungan yang bersifat linear.

\section{Analisis Regresi Berganda}

Berdasarkan hasil analisis regresi berganda, dapat disusun persamaan regresi berganda linear sebagai berikut:

$$
\begin{aligned}
& Y=1,120-0,040 X_{1}+1,869 X_{2}- \\
& 0,009 X_{3}-0,930 X_{4}+0,496 X_{5}+e
\end{aligned}
$$

Keterangan :

$Y$ : Praktik Perataan Laba (Income Smoothing)

$\mathrm{X}_{1}$ : Ukuran Perusahaan (SIZE)

$\mathrm{X}_{2}$ : Net Profit Margin (NPM)

$\mathrm{X}_{3}$ : Debt To Equity Ratio (DER)

$\mathrm{X}_{4}$ : Kepemilikan Manajerial

$X_{5}$ : Reputasi Auditor e = error

\section{Analisis Pengujian Hipotesis}

\section{Uji Signifikan Parsial (Uji Statistik t)}

Berikut adalah hasil pengujian dalam penelitian ini :

Tabel 5

Uji Secara Parsial (Uji t)

\begin{tabular}{|c|c|c|c|}
\hline Model & B & Signifikansi & Keterangan \\
\hline SIZE & -.040 & .523 & Sig $>5 \%$ \\
\hline NPM & 1.869 & .093 & Sig $<10 \%$ \\
\hline DER & -.009 & .949 & Sig $>5 \%$ \\
\hline KPMJ & -.930 & .487 & Sig $>5 \%$ \\
\hline RA & .496 & .015 & Sig $<5 \%$ \\
\hline
\end{tabular}

Sumber: Output SPSS Ver 22.0
Berdasarkan tabel diatas, pengujian hipotesis dalam penelitian ini dapat dijabarkan sebagai berikut: (1) Ukuran Perusahaan (SIZE) memiliki nilai koefisien beta $-0,040$ dan nilai signifikansi $0,523>0,05$ yang artinya variabel ukuran perusahaan tidak berpengaruh secara signifikan terhadap praktik perataan laba. (2) Net Profit Margin (NPM) memiliki nilai keofisien beta 1,869 dan nilai signifikansi $0,093<0,1$ yang artinya variabel net profit margin berpengaruh positif signifikan di $\alpha$ $=10 \%$ terhadap praktik perataan laba. (3) Debt to Equity Ratio (DER) memiliki nilai koefisien beta $-0,009$ dan nilai signifikansi $0,949>0,05$ yang artinya variabel Debt to Equity Ratio tidak berpengaruh secara signifikan terhadap praktik perataan laba. (4) Kepemilikan Manajerial (KPMJ) memiliki nilai keofisien beta $-0,930$ dan nilai signifikansi 0,387 $>0,05$ yang artinya variabel kepemilikan manajerial tidak berpengaruh secara signifikan terhadap praktik perataan laba. (5) Reputasi Auditor (RA) memiliki nilai koefisien beta 0,496 dan nilai signifikansi $0,015<0,05$ yang artinya veriabel reputasi auditor berpengaruh positif signifikan terhadap praktik perataan laba.

\section{Uji Signifikansi Simultan (Uji Statistik F)}

Tabel 6

Uji Secara Simultan (Uji F)

\begin{tabular}{|c|c|c|}
\hline Model & F & Signifikansi \\
\hline Regression & 2.850 & $.019^{\mathrm{b}}$ \\
\hline
\end{tabular}

a.Dependent Variable: IS

b.Predictor: (Constant), RA, DER, NPM, KPMJ, SIZE

Penelitian ini menunjukan bahwa adanya pengaruh yang signifikan antara ukuran perusahaan, net profit margin, 
debt to equity ratio, kepemilikan manajerial, dan reputasi auditor terhadap praktik perataan laba pada perusahaan manufaktur yang terdaftar di Bursa Efek Indoensia selama tahun 2011-2014, hal tersebut dapat dilihat hasil dalam tabel 4.16. Dalam tabel uji secara simultan atau uji $F$ tersebut diketahui bahwa nilai siginifikansi yang diperoleh yaitu $0,019^{b}$, dimana $0,019<0,05(\alpha=5 \%)$ yang berarti Ho ditolak dan H6 diterima. Sehingga dugaan hipotesis yang menyatakan bahwa "ukuran perusahaan, net profit margin, debt to equiry ratio, kepemilikan manajerial, dan reputasi auditor berpengaruh secara simultan terhadap praktik perataan laba" diterima. Dengan demikian dapat disimpulkan bahwa ukuran perusahaan, net profit margin, debt to equiry ratio, kepemilikan manajerial, dan reputasi auditor secara bersama-sama berpengaruh signifikan terhadap praktik perataan laba pada perusahaan manufaktur yang terdaftar di Bursa Efek Indonesia.

Koefisien Determinasi $\left(R^{2}\right)$

Tabel 7

Uji Koefisien Determinasi

\begin{tabular}{|c|c|c|c|c|c|}
\hline $\begin{array}{l}\text { Mo } \\
\text { del }\end{array}$ & $\mathbf{R}$ & $\begin{array}{c}\text { R } \\
\text { Squar } \\
\text { e }\end{array}$ & $\begin{array}{l}\text { Adj. R } \\
\text { Square }\end{array}$ & $\begin{array}{l}\text { Std. Error of the } \\
\text { Estimate }\end{array}$ & $\begin{array}{l}\text { Durbin- } \\
\text { Watson }\end{array}$ \\
\hline 1 & $\begin{array}{l}.36 \\
4^{\mathrm{a}}\end{array}$ & $\begin{array}{c}13 \\
3\end{array}$ & .086 & .72056 & 1.973 \\
\hline
\end{tabular}

Sumber : Output SPSS Ver 22.0

Berdasarkan hasil perhitungan di atas, menunjukkan bahwa nilai koefisien determinasi yang dilihat dari nilai Adjusted $R$ Square sebesar 0,086 yang menunjukkan variabel perataan laba mampu dijelaskan oleh variabel ukuran perusahaan, net profit maergin, debt to equity ratio, kepemilikan manajerial, dan reputasi auditor yaitu sebesar 0,086 atau $8,6 \%$ sedangkan selebihnya yaitu $91,4 \%$ dapat dijelaskan oleh faktor lain yang tidak diteliti dalam penelitian ini.

\section{Pembahasan}

\section{Pengaruh Ukuran Perusahaan Terhadap Praktik Perataan Laba}

Penelitian ini menunjukkan bahwa adanya pengaruh negatif tidak signifikan antara ukuran perusahaan (SIZE) terhadap praktik perataan laba. Hal ini dapat dilihat dari hasil statistik uji t yang menunjukkan bahwa variabel ukuran perusahaan memiliki nilai koefisien beta $-0,040$ dan nilai signifikan 0,525 dimana nilai 0,523 > 0,05 . Hal tersebut menunjukkan bahwa semakin besar ukuran perusahaan, maka indeks perataan laba tinggi, sehingga praktik perataan laba menurun. Dengan demikian $\mathrm{H}_{1}$ ditolak.

Perusahaan yang memiliki total aset yang besar cenderung untuk tidak melakukan praktik perataan laba. Berdasarkan hasil penelitian bahwa perusahaan yang menjadi sampel penelitian termasuk kedalam perusahaan yang dikategorikan sebagai perusahaan besar. Menurut Badan Standarisasi Nasional suatu perusahaan dapat dikategorikan sebagai perusahaan yang berukuran besar apabila memiliki nilai kekayaan bersih lebih dari $\mathrm{Rp}$ 10.000.000.000,-. Dengan melihat data total aset dari perusahaan yang menjadi sampel penelitian bahwa seluruh perusahaan tersebut dapat dikategorikan sebagai perusahaan besar, karena memiliki nilai total aset yang lebih dari Rp 10.000.000.000,-. Perusahaan besar biasanya menjadi sorotan oleh berbagai pihak seperti pemerintah regulator, 
investor, masyarakat dan lain-lain. Sehingga perusahaan akan lebih berhatihati dalam menyusun laporan keuangan dan melaporkannya sesuai dengan kondisi perusahaan yang sebenarnya.

Hasil penelitian ini konsisten dengan hasil penelitian yang dilakukan oleh Kusnadi (2015) yang menunjukkan hasil bahwa perusahaan yang berukuran besar lebih cenderung untuk tidak melakukan praktik perataan laba, karena perusahaan yang semakin besar akan menjadi sorotan publik dan setiap kegiatan yang dilakukan perusahaan akan mendapat perhatian oleh pihak pemerintah, regulator dan masyarakat umum. Hasil penelitian ini juga sejalan dengan penelitian yang dilakukan oleh Andy Sri Haryadi (2011) namun tidak konsisten dengan hasil penelitian terdahulu yang dilakukan oleh Rahmawati dan Muid (2012) yang dapat membuktikan bahwa ukuran perusahaan berpengaruh signifikan terhadap praktik perataan laba.

Pengaruh Net Profit Margin Terhadap Praktik Perataan laba

Penelitian ini menunjukan hasil bahwa adanya pengaruh positif signifikan antara net profit margin (NPM) terhadap praktik perataan laba. Hal ini dapat dilihat dari hasil statistik uji t yang menunjukan bahwa variabel net profit magin (NPM) memiliki nilai koefisien beta 1,869 dan nilai signifikan 0,093 dimana 0,093 < 0,1 (10\%). Hal tersebut menunjukan bahwa semakin tinggi tingkat net profit margin (NPM), maka indeks perataan laba tinggi sehingga praktik perataan laba menurun yang mengindikasikan perusahaan melakukan praktik perataan laba. Dengan demikian $\mathrm{H}_{2}$ diterima.
Hal ini dikarenakan, perusahaan dengan tingkat net profit margin yang rendah pada tahun sebelumnya, maka kecenderungan manajer untuk melakukan perataan laba semakin besar dengan tujuan untuk meningkatkan kembali nilai profitabilitas perusahaan yang salah satunya net profit margin tersebut, karena dengan tingkat profitabilitas yang tinggi akan dapat menaikkan standar bonus atau laba dimasa yang akan datang. Sehingga kepentingan manajemen tersebut dapat terpenuhi untuk mendapatkan kompensasi berupa bonus dari laba yang besar ditahun berjalan. Jadi dalam hal ini manajemen perusahaan akan menggunakan kebijakannya untuk memilih metode akuntansi yang dapat menambah laba perusahaan.

Hasil penelitian ini konsisten dengan penelitian yang dilakukan oleh Dewi dan Prasetiono (2012) yang menunjukan hasil bahwa net profit margin berpengaruh positif terhadap perataan laba karena margin laba bersih secara logis terkait langsung dengan objek perataan laba. Namun, hasil penelitian ini tidak konsisten dengan penelitian yang dilakukan oleh Rahmawati dan Muid (2012) yang menyatakan bahwa net profit margin tidak berpengaruh terhadap praktik perataan laba.

\section{Pengaruh Debt To Equity Ratio Terhadap}

\section{Praktik Perataan Laba}

Penelitian ini menunjukan hasil bahwa tidak ada pengaruh signifikan antara debt to equity ratio terhadap praktik perataan laba. hal ini dapat dilihat dari hasil statistik uji t yang menunjukan hasil bahwa variabel debt to equity ratio memiliki nilai koefisien beta -,009 dan nilai 
signifikan 0,949 dimana 0,949>0,05. Hal tersebut menunjukkan bahwa semakin tinggi tingkat utang perusahaan maka indeks perataan laba akan tinggi, sehingga praktik perataan laba menurun. Dengan demikian $\mathrm{H}_{3}$ ditolak.

Dalam hal ini, perusahan yang memiliki tingkat hutang yang tinggi, dimana modal yang dimiliki tidak dapat menjamin hutang perusahaan yang artinya perusahaan akan mendekati pada pelanggaran perjanjian utang dengan pihak kreditor, dalam hal ini manajemen perusahaan cenderung untuk tidak memilih metode akuntansi yang dapat meningkatkan laba perusahaan. Sehingga semakin tinggi tingkat hutang akan menurunkan kemungkinan perusahaan untuk tidak melakukan praktik perataan laba.

Hasil tersebut didukung dengan melihat data dari tingkat debt to equity ratio seluruh perusahaan yang menjadi sampel penelitian, memiliki tingkat utang yang bervarisi namun kebanyakan perusahaan memiliki tingkat utang yang dianggap masih aman, karena menurut Suyati (2005) dalam Irham Fahmi (2014) menyatakan bahwa dalam persoalan debt to equity ratio ini, tidak ada batasan berapa debt to equity ratio yang aman bagi suatu perusahaan, namun untuk konservatif biasanya debt to equity ratio yang lewat dari $66 \%$ atau $2 / 3$ sudah dianggap berisiko. Dengan melihat hasil perhitungan DER pada 30 perusahaan yang menjadi sampel penelitian dapat diperoleh hasil yaitu sebanyak 14 perusahaan yang memiliki tingkat debt to equity ratio yang lebih dari $66 \%$, kemudian sebanyak 16 perusahaan memiliki tingkat debt to equity ratio kurang dari $66 \%$. Sehingga dapat disimpulkan bahwa kebanyakan perusahaan memiliki tingkat utang yang aman dan dianggap tidak berisiko.

Hasil penelitian ini sesuai dengan penelitian yang dilakukan oleh Rahmawati dan Muid (2012) yang menyatakan kemungkinan perusahaan melakukan praktik perataan laba dapat disebabkan oleh beberapa hal antara lain yaitu ratarata perusahaan sampel memiliki tingkat utang yang rendah atau dengan kata lain perusahaan tidak bergantung pada utang dalam membiayai modal perusahaannya.

\section{Pengaruh Kepemilikan Manajerial Terhadap Praktik Perataan Laba}

Penelitian ini menunjukan hasil bahwa tidak ada pengaruh signifikan antara pengaruh kepemilikan manajerial terhadap praktik perataan laba. Hal ini dapat dilihat dari hasil statistik uji t yang menunjukan hasil bahwa variabel kepemilikan manajerial memiliki nilai koefisien beta -,930 dan nilai signifikan 0,487 dimana $0,487>0,05$. Hal tersebut menunjukan bahwa semakin besar proporsi kepemilikan manajerial, maka indeks perataan laba tinggi, sehingga praktik perataan laba menurun. Dengan demikian $\mathrm{H}_{4}$ ditolak.

Hal ini dikarenakan bahwa semakin besar proporsi kepemilikan manajerial dalam suatu perusahaan, maka akan dapat meminimaliris agency problem antara manajer (agent) dengan pemegang saham (principal) yang mana dapat menyelaraskan dan mensejajarkan kepentingan antara manajer dengan pemegang saham dikarenakan manajer 
perusahaan tersebut berperan juga sebagai pemegang saham perusahaan, sehingga informasi yang dimiliki oleh manajer kemungkinan akan disampaikan secara obyektif kepada para pemegang saham. Namun, dengan melihat hasil pengujian yang menunjukan bahwa kepemilikan manajerial tidak berpengaruh signifikan terhadap praktik perataan laba diduga karena saham yang dimiliki pihak manajemen yang terdiri dari manajer, dewan komisaris dan dewan direksi ratarata memiliki kepemilikan saham yang rendah atau saham minoritas dibandingkan dengan kepemilikan saham institusional dan publik.

Hasil penelitian ini sejalan dengan penelitian yang dilakukan oleh Kusnadi (2014) dengan arah beta yang sama yaitu negatif (-) namun dengan hasil pengujian yang berbeda yaitu tidak berpengaruh signifikan sedangkan penelitian yang dilakukan sebelumnya oleh Kusnadi menyatakan berpengaruh signifikan

\section{Pengaruh Reputasi Auditor Terhadap Praktik Perataan laba}

Penelitian ini menunjukkan hasil bahwa adanya pengaruh positif signifikan antara reputasi auditor terhadap praktik perataan laba. Hal ini dapat dilihat dari hasil statistik uji t yang menunjukkan hasil bahwa variabel reputasi auditor memiliki nilai koefisien beta 0,496 dan nilai signifikan 0,015. Dimana 0,015 < 0,05. Hal tersebut menunjukkan bahwa semakin tinggi nilai reputasi auditor yang artinya semakin baik reputasi auditor tersebut, maka nilai indeks perataan laba akan tinggi, sehinggga praktik perataan laba menurun. Dengan demikian $\mathrm{H}_{5}$ diterima. Sehingga hasil penelitian menunjukkan bahwa perusahaan yang menggunakan auditor yang bereputasi baik yang bergabung dengan KAP the big four dapat mengurangi praktik perataan laba yang dilakukan oleh perusahaan.

Sementara, pengaruh lain yang dapat mendorong perusahaan untuk melakukan praktik perataan laba karena sedikitnya perusahaan yang menggunakan Kantor Akuntan Publik (KAP) The Big Four. Kemudian, dapat dibuktikan juga dengan melihat hasil perhitungan data perusahaan selama tahun pengamatan yaitu 2011-2014 kebanyakan perusahaan menggunakan jasa akuntan publik yang tidak beafiliasi dengan KAP The Big Four melainkan dengan menggunakan KAP Non Big Four. Sehingga dapat disimpulkan bahwa perusahaan yang melakukan praktik perataan laba yaitu sebuah perilaku yang dapat merugikan para pemakai laporan keuangan terutama para investor. Akan menghindari penggunaan jasa akuntan publik yang berafiliasi dengan KAP The Big Four dan lebih memilih menggunakan KAP Non Big Four. Karena KAP the big four dianggap lebih kompeten dan profesional serta memiliki pengetahuan lebih banyak tentang cara mendeteksi dan membatasi manipulasi laporan keuangan lebih dini yang dilakukan perusahaan dibanding KAP non big four. Hal tersebut dapat dibuktikan, jika melihat hasil dari perhitungan data reputasi auditor yang diproksikan dengan ukuran KAP, yang mana hasil perhitungan menunjukan bahwa hanya $41,7 \%$ perusahaan yang menggunakan KAP the big four dan selebihnya menggunakan KAP non big four. 
Hasil penelitian ini sesuai dengan penelitian yang dilakukan oleh Firdaus (2015) namun dengan hasil nilai koefisien beta yang berbeda yang mana dalam penelitian Firdaus (2015) menunjukan nilai koefisien beta dengan arah tanda negatif (-) yang artinya perusahaan yang menggunakan KAP The Big Four dapat membatasi perusahaan untuk melakukan praktik perataan laba. sedangkan hasil dari penelitian ini menunjukan nilai koefisien beta berarah positif $(+)$ yang artinya auditor yang bergabung dalam KAP big four lebih kompeten, berintegritas dan professional dalam memeriksa dan memberikan pengesahan atas kebenaran dalam penyusunan laporan keuangan dibandingkan dengan auditor non big four, karena auditor big four memiliki pengetahuan yang lebih banyak tentang cara mendeteksi perilaku yang akan mempengaruhi laporan keuangan atau manipulasi laba yang salah satunya yaitu praktik perataan laba.

\section{KESIMPULAN DAN SARAN}

\section{Kesimpulan}

Dari hasil pengujian secara parsial menunjukan hasil bahwa variabel ukuran perusahaan tidak berpengaruh signifikan terhadap praktik perataan laba, variabel net profit margin (NPM) berpengaruh positif signifikan terhadap praktik perataan laba, variabel debt to equity ratio (DER) tidak berpengaruh signifikan terhadap praktik perataan laba, variabel kepemilikan manajerial tidak berpengaruh signifikan terhadap praktik perataan laba. Sedangkan variabel reputasi auditor berpengaruh positif signifikan terhadap parktik perataan laba. Dari hasil pengujian secara bersama-sama atau simultan ukuran perusahaan, net profit margin, debt to equity ratio, kepemilikan manajerial dan reputasi auditor terhadap praktik perataan laba pada perusahaan manufaktur yangterdaftar di Bursa Efek Indonesia pada tahun 2011-2014.

\section{Saran}

Berdasarkan hasil penelitian dan kesimpulan diatas, maka saran yang dapat direkomendasikan dalam penelitian ini adalah sebagai berikut:

1. Bagi peneliti selanjutnya disarankan untuk menambah periode pengamatan, menambah perusahaan sektor lain yang tidak hanya sektor manufaktur saja seperti sektor keuangan dan non keuangan yang terdaftar di Bursa Efek Indonesia untuk tujuan menambah sampel perusahaan sehingga generalisasi hasil penelitian akan lebih luas dan lebih akurat.

2. Menambahkan variabel-variabel independen lain yang tidak digunakan dalam penelitian ini sebagai faktor yang dapat mempengaruhi praktik perataan laba seperti sales growth, struktur kepemilikan institusional, jumlah kepemilikan publik dan variabel nilai perusahaan sebagai variabel dependen. Agar penelitian serupa kedepannya dapat mengurangi keterbatasan yang terjadi pada penelitian ini.

3. Menggunakan proksi pengukuran lain untuk mengukur perataan laba dalam perusahaan seperti model Michelson (1995) yang membedakan perusahaan perata laba dan bukan perata laba berdasarkan koefiisen variasi obyek perataan dengan koefisien pendapatan. Agar hasil klasifikasi tersebut dapat digunakan untuk menguji konsistensi dan mengurangi 
keterbatasan dari hasil peneltian terdahulu.

4. Bagi pihak investor dalam pengambilan keputusannya dalam berinvestasi disarankan sebaiknya tidak hanya memusatkan perhatian kepada kondisi laba perusahaan saja, namun juga untuk melihat pada keadaan keuangan perusahaan serta rasio-rasio keuangan lainnya, karena terbukti bahwa adanya tindakan praktik perataan laba yang masih cukup banyak yang dilakukan oleh perusahaan go public di Indonesia.

5. Bagi perusahaan diharapkan dapat meningkatkan dan menambah pihak lain untuk mengawasi kegiatan operasional perusahaan agar terhindar dari perilaku manajemen yang ingin melakukan tindakan yang dapat mengurangi tingkat reliable suatu laporan keuangan yang terletak pada laba perusahaan yang berdampak pada nilai perusahaan

6.

\section{DAFTAR PUSTAKA}

Dewi Kartika Shintia, dan Prasetiono. 2012. "Analisis Pengaruh ROA, NPM, DER, Dan SIZE Terhadap Praktik Perataan Laba (Studi Ksus Pada Perusahaan Manufaktur Ynag Terdaftar Di Bersa Efek Indonesia Periode 2007-2010)." Diponegoro Journal of

Dewi, Ratih Kartika dan Dra Hj. Zhulaikha, M.Si, Akt (2009). "Analisis FaktorFaktor Yang Mempengaruhi Perataan laba (Income Smoothing) Pada Perusahaan manufaktur Dan Keuangan Yang Terdaftar Di BEI". Jurnal. Universitas Diponegoro Semarang.

Dul Muid, Rahmawati Dina. 2012. "Analisis Faktor-Faktor Yang Berpengaruh
Terhadap Praktik Perataan Laba (Studi Pada Perusahaan Manufaktur Yang Terdaftar di BEI Tahun 2007-2010)." Diponegoro Journal of Accounting volume 1, No 2, Hal 1-14.

Eckel, Norm. 1981. "The Income Smoothing Hypothesis Revisited". Abacus. Vol 17. No. 1. Pp. 28-40

Eckel, Norm. 1981. "The Income Smoothing Hypothesis Revisited Abacus, June: 28-40 Financial Accounting Standards Boards 1978. Statement of Financial Accounting Concept No. 1: objectives of Financial Reporting by business enterprises"

Fahmi, Irham. 2014. Pengantar Manajemen Keuangan Teori dan Soal Jawab. Bandung: Alfabeta.

Firdaus, Akmal. 2015. “Analisis Pengaruh Profitabilitas, Reputasi Auditor, dan Ukuran Perusahan Terhadap Perilaku Income Smoothing." Skripsi. Program Sarjana Fakultas Ekonomika Dan Bisnis. Universitas Diponegoro Semarang.

Ghozali, Imam Prof Dr M Com Akt, 2013. Aplikasi Analisis Multivariate dengan Program IBM SPSS 21. Semarang: Universits diponegoro

Jensen, Michael C. dan William $H$. Meckling. 1976. "Theory of the firm Managerial Behavior, Agency costs and Ownership Structure". Journal of Financial Economic, October, 1976. Vol 3. No. 4 pp. 305-360

Jin, Liauw She dan Mas'ud Machfoedz. 1998. "Faktor-Faktor yang Mempengaruhi Praktik Perataan 
Laba Pada Perusahaan yang

Terdaftar di Bursa Efek Jakarta". Jurnal Riset Akuntansi Indonesia.

Vol 1 No. 2

Kusnadi, 2015. Pengaruh Profitabilitas, Debt to Equity Ratio, Struktur Kepemilikan Manajerial, Ukuran Perusahaan dan Risiko Keuangan Terhadap Praktek Perataan Laba Pada Perusahaan Yang Terdaftar di Bursa Efek Indonesia Periode Tahun 2010-2013. Jurnal Vol 1 No 1. ISSN: $2442-4056$

Noviana R. Sindi. 2012. "Analisis Faktor-

Faktor Yang Mempengaruhi Praktik Perataan Laba (Studi Empiris Perusahaan Manufaktur Yang Terdaftar Di BEI Periode 2006-2010)" Srripsi Dipublikasikan Fakultas Ekonomika Dan Bisnis Universitas Diponegoro Semarang. Octavania Meliza, Asyik Nur Fadjrih. 2014.

"Pengaruh Ukuran Perusahaan, Pertumbuhan Perusahaan, dan Kepemilikan Manajerial Terhadap Praktik Perataan Laba." Sekolah Tinggi Ilmu Ekonomi Indonesia (STIESIA) Surabaya. Jurnal IImu \& Riset Akuntansi Vol. 3 No. 6

Pratiwi Herlina Dan Handayani Dwi Bestari. 2014. "Pengaruh Profitabilitas, Kepemilikan Manajerial, Dan Pajak Terhadap Praktik Perataan Laba". Accounting Analysis Journal. Vol. 3 No. 2

Primatama Willy Arbiyanto. 2015.

"Pengaruh Company Size, Return On Asset, Net Profit Margin, Financial Laverage dan Operating Profit Margin Terhadap Praktik Income Smoothing" Jurnal
Akuntansi dan Sistem Teknologi Informasi, Vol. 11 Hal. 304-311

Riahi Ahmed-Belkaoui, 2006. Accounting Theory, Jakarta: Salemba Empat

Riahi Ahmed-Belkaoui, 2011. Accounting Theory, Jakarta: Salemba Empat

Salno, H.M. dan Z. Baridwan. 2000. Analisis Perataan Penghasilan (Income Smoothing): Faktor-faktor yang mempengaruhi dan kaitannya dengan kinerja saham perusahaan publik di Indonesia. Jurnal Riset Akuntansi Indonesia. Vol. 3, No 1 Januari

Sofyan, Syafri Haraphap, 2012. Teori Akuntansi (Edisi Revisi 2011). Edisi ke 12. Jakarta: PT Raja Grafindo Persada

Sugiyono. 2014. Metode Penelitian Kuantitatif Kualitatif dan kombinasi Cetakan ke-5. Bandung: Alfabeta

Sulistiyawati. 2013. "Pengaruh Nilai Perusahaan, Kebijakan Dividen, Dan Reputasi Auditor". Accounting Analisys Journal Vol 2, No. 2

Suwito, Edy dan Arleen Herawaty. 2005. Analisis Pengaruh Karakteristik Perusahaan Terhadap Tindakan Perataan Laba yang dilakukan Oleh Perusahaan yang Terdaftar di BEJ. Dalam SNA VIII Solo. September 2005.

Widyaningdyah, Agnes; 2001, Analisis Faktor-Faktor Yang Berpengaruh Terhadap Earning Management Pada Perusahaan Go Publik di Indonesia, Jurnal Ekonomi Akuntansi, Fakultas Ekonomi Universitas Kristen Petra. 
Yasa Wirawan dan Prabayanti Arik. 2010. “

Perataan Laba (Income Smoothing)

Dan Analisis Fattor-faktor Yang

Mempengaruhinya (Studi Pada

Perusahaan Manufaktur yang

Terdaftar Di Bursa Efek Indonesia)"

Jurnal.

Yuyetta Afif dan Noviana Retno Sindi.

2011. "Analisis Faktor-Faktor yang mempengaruhi Praktik Perataan

Laba (Studi Empiris Perusahan

Manufaktur Yang terdaftar di BEI

Periode 2006-2010)" Jurnal

Akuntansi \& Auditing. Vol. 8 No. 1

Hal. 1-94

www.idx.co.id

www.sahamok.com 